\title{
Correction of Four Specific Epithets That Are Hyphenated in the Approved Lists of Bacterial Names
}

\author{
J. J. FARMER III \\ Enteric Bacteriology Section, Center for Infectious Diseases, Centers for Disease Control, Atlanta, Georgia \\ 30333 \\ Four species were listed in the Approved Lists of Bacterial Names with \\ hyphenated specific epithets, which is in conflict with Rule 12a of the Internation- \\ al Code of Nomenclature of Bacteria. The hyphens are dropped, and the names \\ are corrected to Nocardia otitidiscaviarum, Propionibacterium acidipropionici, \\ Salmonella choleraesuis, and Treponema paraluiscuniculi.
}

The Approved Lists of Bacterial Names (2) contains four species which have hyphenated specific epithets: Nocardia otitidis-caviarum (p. 338), Propionibacterium acidi-propionici (p. 346), Salmonella cholerae-suis (p. 360), and Treponema paraluis-cuniculi (p. 416). Rule 12a of the International Code of Nomenclature of Bacteria (1, p. 15) states that,

"If a specific epithet is formed from two or more words, then the words must refer to a single concept and are to be joined. If the words were not joined in the original publication, then the epithet is not to be rejected, but the form is to be corrected by joining the words, which can be done by any author. If an epithet has been hyphenated, its parts should be joined. The name retains its validity and standing in nomenclature."

Thus, the correct ways to write the names of the four species are Nocardia otitidiscaviarum, Propionibacterium acidipropionici, Salmonella choleraesuis, and Treponema paraluiscuniculi, rather than with hyphenated specific epithets as in the Approved Lists.

\section{LITERATURE CITED}

1. Lapage, S. P., P. H. A. Sneath, E. F. Lessel, V. B. D. Skerman, H. P. R. Seellger, and W. A. Clark (ed.). 1975. International code of nomenclature of bacteria. 1975 Revision. American Society for Microbiology, Washington, D.C.

2. Skerman, V. B. D., V. McGowan, and P. H. A. Sneath (ed.). 1980. Approved lists of bacterial names. Int. J. Syst. Bacteriol. 30:225-420. 